\title{
Fundo de Pesquisa \\ "Gustavo de Oliveira Castro"
}

\section{Luiz Fernando Ferreira}

Está razoavelmente estabelecida a maneira de se avaliar um progama de pesquisa, bem como a formação de um jovem cientista. $E$ assim funcionam as agências financiadoras e os programas de pós-graduação.

Entretanto as exceçōes existem. E de grande peso. Seyle comentava as dificuldades que teve no início de sua carreira por trabalhar um tanto fora dos padröes estabelecidos. Watson teve sua bolsa de estudos cancelada pelo fato da comissão não considerá-lo capacitado a ingressar na área de pesquisa onde obteve o prêmio Nobel, ao desvendar a estrutura do DNA. Pasteur é um químico que vai revolucioniar a medicina, e em 1910 a Doença de Chagas não seria considerada como progama prioritário. São inúmeros os exemplos. Coisas importantes acontecem fora da ortodoxia, fora dos padrões estabelecidos de julgamento.

Nesse sentido, a Fundação Oswaldo Cruz resolveu estabelecer o Fundo de Pesquisa Gustavo de Oliveira Castro a fim de identificar, estimular e de financiar idéias originais na área das ciências biológicas em seu sentido mais amplo. Não se pretende competir com as agências estabelecidas. $O$ nosso interesse é exatamente nos projetos pouco ortodoxos, aqueles que teriam dificuldajes em obter financiamento segundo os padrões clássicos estabelecidos. Nossos recursos ambém são pequenos. Não temos formulários padronizados, nem exígimos títulos ou formação acadêmica. Estamos dando os primeiros passos guiados por uma idéia que necessita ser aperfeiçoada pouco a pouco. Sugestōes sobre a maneira de atingir nosso objetivo serão bem recebidas.

No ano passado três projetos foram escolhidos:

- Transplante de nervo ciático entre dois hemisférios cerebrais de hamsters - um experimento de engenharia neural.

Responsável: Roberto Lent, Laboratório de Neuroplasticidade - Insti tuto de Biofísica Carlos Chagas Filho - UFRJ.

Colaborador: Ciro Ferreira da Silva, Departamento de Anatomia - Universidade de São Paulo. 
- Utilização de água de coco como meio de cultivo de protozoários de interesse médico: gênero Leishmania.

Proponente: Carlos Roberto Alves - Biólogo estagiário do Departamento de Ciências Biológicas - ENSP.

- Proposta para desenvolvimento, experimentação e montagem de um sistema biotecnológico destinado a detectar estado pré-anêmico sem estabelecer contato direto com o fluido sanguíneo.

Roberto Cavalcanti - Pesquisador e projetista de sistemas biotecnológicos.

Pedro Paulo Fernandes Mesquita - Engenheiro mecânico - projetista de sistemas e pesquisador em ciência eletrônica.

O julgamento se fez, basicamente, levando em conta a coerência entre a metodologia de trabalho proposta e o problema original apresentado.

\section{GUSTAVO DE OLIVEIRA CASTRO}

Gustavo de Oliveira Castro era colega de turma de meu pai, na Faculdade de Medicina, e foi um dos ídolos da minha adolescência. E eu diria que ainda é, até hoje. A amplidão dos seus conhecimentos me fascinava. Era em primeiro lugar um naturalista completo, como raros, já na sua época. Lembro-me perfeitamente de uma tarde em Manguinhos, na porta do Castelo em que ele dissertava para uma pequena platéia, entre encantada e admirada, sobre a acentuação tônica no grego arcaico.

Entre suas contribuições à ciência, talvez a mais importante, está intimamente relacionada com seus profun dos conhecimentos de botânica. Ciência que cultivou desde os bancos de estudante, em estágios no Jardim Botânico com Pacheco Leão. Em 1946 publica nos anais da Academia Brasileira de Ciências (v.18, $\mathrm{n}^{\circ}$. 2) "Filogênese e sucessão" e no ano seguinte "Um método de análise de populaçōes vegetais" (Mem. Inst. Oswaldo Cruz 45 (3): 572-586).

Segundo Mário Aragão: "Elas revelam a força de um naturalista com uma ampla formação científica e que pensa, nas coisas que observa" e continua: "Oliveira Castro foi muito criticado por ser dispersivo e pouco produtivo. Acreditamos entretanto, que foram 
essas duas facetas de sua personalidade que o conduziram a formular a lei da filogênese e sucessão: "Em cada sere a distribuição dos seres vivos não se faz por acaso: os menos diferenciados têm freqüência relativamente maior nos estados pioneiros e os mais diferenciados nos habitates estáveis. Em outras palavras as plantas e animais que vivem na vegetação aberta são menos evoluídos do que aqueles que habitam a floresta".

Oliveira Castro nasceu em Petrópolis, em 1904. Trabalhou no Instituto Biológico em Săo Paulo e no Instituto de Biologia Animal do Ministério da Agricultura. Vem para Manguinhos para estagiar com o Dr. Lutz e aqui permanece, tendo ocupado vários cargos. Em 1947 aposentou-se por limite de idade, tendo entretanto continuado a trabalhar até as vésperas de sua morte. Foi também, Membro Titular da Academia Brasileira de Ciências.

Publicou vários trabalhos em diferentes áreas da Biologia, tendo-se dedicado mais especialmente a entomologia botânica e ecologia. Em 1959 publica com Stanley Cain "Manual of vegetation analysis" (Harper \& Brothers, Publishers, New York, 1959).

Sua maneira de ser distraída, sua despreocupação com o vestir-se faziam dele uma pessoa bastante original. E fascinante. Impressionado com a sua cultura, tanto científica como geral, o Dr. Lutz se referia a ele, como uma avis rara. E Lutz não era homem de elogios fáceis.

Convivi com ele mais intimamente nos últimos anos de sua vida, quando ia visitá-lo no seu laboratório no Pavilhão de Biologia, especialmente ecologia. Nessa época estava interessado na formulação matemática da sua teoria. Visitei-o pela última vez em sua casa, no Humaitá. Simon Schwartsman que preparava nessa época Formação da comunidade científica no Brasil queria entrevistá-lo. Infelizmente, não deu tempo.

Aprendia-se muito conversando com Gustavo de Oliveira Castro.

Cartas para a secretária executiva:

Ana Lucia Almeida de Larrive

Superintendência de Planejamento (Suplan )

Fiocruz

Av. Brasil, 4365

Pavilhão Figueiredo Vasconcellos

$3^{\circ}$. andar - s/305

Manguinhos 